\title{
How Unreliable Factfinding Can Undermine Sentencing Guidelines
}

\author{
Peter B. Pope $\nmid$
}

Over the last decade, forces from across the political spectrum have been attacking sentence disparity-the sentencing of like cases differently. ${ }^{1}$ Most frequently, disparity is attributed to the enormous discretion that judges have enjoyed in imposing sentences. ${ }^{2}$ With little statutory guidance ${ }^{3}$ and virtually no appellate review, ${ }^{4}$ sentencing judges in most jurisdictions have been left to themselves to decide what facts about a crime or a criminal are at all relevant to a sentence, and how those facts ought to affect

I I would like to thank the Daniel and Florence Guggenheim Criminal Justice Program at the Yale Law School for graciously permitting me to use the data gathered by the Sentencing Project. I would also like to thank those who organized and participated in the project, but particularly Professors Daniel J. Freed and Milton Heumann and Justice Harold J. Rothwax.

1. Panel on Sentencing Research, National Research Council, 1 Research on Sentencing: The SEARch for Reform 72 (1983) [hereinafter cited as Sentencing Research]. Society's concern with sentence disparity is reflected in the legislative history that accompanied the Sentencing Reform Act of 1984, Pub. L. No. 98-473, $\S 211-39,98$ Stat. 1987 (codified in scattered sections of U.S.C.): "The shameful disparity in criminal sentences is a major flaw in the existing criminal justice system, and makes it clear that the system is ripe for reform." S. REP. No. 225, 98th Cong., 2d Sess. 65, reprinted in 1984 U.S. Cone Cong. \& AD. News 3182, 3248 (Senate Committee on the Judiciary) (discussing S. 1762, from which Congress drew much of Sentencing Reform Act of 1984). State legislatures have echoed the sentiment, see 1983 N.Y. Laws ch. 711, § 2(1) ("Similar crimes committed under similar circumstances by similar offenders should receive similar sanctions"), as have judges, see M. Frankel, Criminal. Sentences: Law Wrthout Order (1972) [hereinafter cited as Criminal Sentences], and academicians, see P. O'Donneli, M. Churgin, \& D. Curtis, Toward a Just and Effective Sentencing System: Agenda for Legislative Reform (1977) [hereinafter cited as LegisLAtive AGENDA]. For a discussion of the breadth of concern with sentencing reform, see SENTENCING RESEARCH, supra, at 65 (By late 1970's "a broad consensus in favor of change had formed among the political left and right, law enforcement agencies and prisoners' groups, and reformers and criminal justice systems officials.").

2. See, e.g., Criminal Sentences, supra note 1 , at 69 ("It is far from a novelty to contend . . . that the sweeping power of a single judge to determine the sentence, as a matter of largely unreviewable 'discretion,' is a-perhaps 'the'-central evil in the system."); Legislative AGENDA, supra note 1 , at 10 ("Substantial disparities are the inevitable result of judicial discretion exercised by 378 federal district judges across the country .....").

3. Legislatures typically have provided judges with enormous statutory ranges within which they may sentence. For instance, in the District of Columbia, a judge may sentence a convicted robber to anywhere from 2 to 15 years. D.C. CODE ANN. $\$ 22-2901$ (1981). Although this range allows judges to sentence one robber to a term seven times as long as another, the statute gives no guidance as to who deserves the fifteen years and who the two. See id.

4. See United States v. Tucker, 404 U.S. 443,447 (1972) ("[A] sentence imposed by a federal district judge, if within statutory limits, is generally not subject to review."). See also Symposium, Appellate Review of Sentences, 32 F.R.D. 257, 260-61 (1962) (Remarks of Kaufman, J.) ("At present the United States is the only nation in the free world where one judge can determine, conclusively, decisively and finally the minimum period of time a defendant must remain in prison, without being subject to any review of his determination."), quoted in, Dorszynski v. United States, 418 U.S. 424,440 n.14 (1974). 
sentence length. As a consequence, judges have been able-indeed they have virtually been forced-to sentence on the basis of their own philosophy of criminal law. This has created a situation in which one judge might grant probation for the same case that, in the next courtroom, another might impose ten years. As former Judge Marvin Frankel has said: "[S]weeping penalty statutes allow sentences to be 'individualized' not so much in terms of defendants but mainly in terms of the wide spectrums of character, bias, neurosis, and daily vagary encountered among occupants of the trial bench."

Accordingly, reformers have sought to curtail disparity by limiting judicial discretion. For instance, between 1975 and 1982 more than 30 states passed mandatory minimum sentencing laws. ${ }^{6}$ Today a legislatively fashionable way of controlling discretion is through "Sentencing Guidelines," rules that direct sentencers how sentence length should change as salient facts in a case vary. ${ }^{2}$

5. Criminal Sentences, supra note 1 , at 21 .

6. SENTENCING ReSEARCH, supra note 1 , at 61 .

7. The nation's first sentencing guideline commission was established in Minnesota in 1978. D. Parent, The Minnesota Sentencing Guideline Process ch.1, at 1 (forthcoming 1986). In 1980, the first version of the Minnesota Guidelines went into effect, id., and the updated version still is, see MinN. Stat. ANN. ch. 244-app. (West Supp. 1985) (Minnesota Sentencing Guidelines \& Commentary). Widely viewed as successful in achieving its objectives, the Minnesota system has served as a model for other jurisdictions considering guidelines. Since Minnesota broke the ground, the states of Washington, WASH. REv. CODE. ANN. $\$ 9.94 A .310$ (Supp. 1985) (Washington Sentencing Grid), and Pennsylvania, 204 PA. AdMIN. CodE $\$ \S 303.1-03.9$ (Fry 1986) (Pennsylvania Sentencing Guidelines), have enacted guidelines as well.

More recently, the New York State legislature established a sentencing committee to draft guidelines for the legislature to consider. 1983 N.Y. Laws ch. 711. The New York Committee chose to follow the grid form, see Minutes of the Meeting of New York State Committee on Sentencing Guidelines 6-7 (Mar. 30, 1984), and, as a result, their product looks much like Minnesota's grid-offense severity on the vertical axis, offender history on the horizontal. See NEW YORK STATE COMMITTEE on Sentencing Guidelines, Determinate Sentencing Report and Recommendations 56 (Mar. 29, 1985) (reproduction of grid) [hereinafter cited as N.Y. Guideline RePORT]. Unlike the Minnesota Guidelines, which in the absence of legislative action automatically went into effect after promulgation and a lay-over period, MinN. STAT. ANN. $§ 244.09$, Subd. 12 (West Supp. 1985), the New York Guidelines "have no force and effect unless enacted [by the legislature] into law." 1983 N.Y. Laws ch. 711 \$3(1). Published by the New York Guidelines Committee in March 1985, the New York Guidelines have gathered scant support, and the chances of their enactment into law seem slim.

In Washington, D.C., the Chief Judge of the District of Columbia Superior Court has established a committee of judges and non-judges to develop guidelines. Judge Frederick H. Weisberg, Remarks to Guggenheim Sentencing Project Seminar, Yale University (Mar. 1, 1985) (tape on file with Guggenheim Project). Their proposal has not yet been made public.

For years, the federal government has used a shadow sentencing guideline system in the guise of parole guidelines. See 28 C.F.R. § 2.20 (1985) (parole guidelines); 44 Fed. Reg. 26,549 (1979) (arguing that parole guidelines mitigate sentence disparity). Thinking it politically infeasible to impose sentencing guidelines on district court judges, Congress attacked sentence disparity through the parole board. It set up a guideline system for the U.S. Parole Commission which was analytically identical to sentencing guidelines. Thus the Parole Commission became the de facto sentencer in federal crimes. See United States v. Addonizio, 442 U.S. 178, 188-9 (1979) ("Whether wisely or not, Congress has decided that the [Parole] Commission is in the best position to determine when release is appropriate, and in doing so, to moderate the disparities in the sentencing practices of individual judges."). This 
In this essay, I will argue that, in the war against disparity, the tacticians of the guidelines movement have paid insufficient attention to the procedures that develop the facts to which guidelines are applied. Tacking shiny, new sentencing guidelines onto the tail end of a system of criminal procedure which does an unreliable job of developing the facts (as so many of the nation's criminal justice systems do) is a lot like putting a new coat of paint on an old clunker. The car looks good, but it still doesn't run much better. Ironically, sentencing guidelines may entrench a different kind of disparity-factual disparity.

\section{The Minnesota Guidelines As Model}

The archetypical sentencing guideline system is the Minnesota Guidelines, which have been in effect since $1980 .^{8}$ The Minnesota system has become a model for reform in other jurisdictions, ${ }^{9}$ and exhibits the four traits which best characterize modern sentencing grids: 1) it identifies the set of facts relevant to sentencing, ${ }^{10} 2$ ) it determines how these relevant facts will affect a sentence; ${ }^{11} 3$ ) it allows the sentencer to depart from the indicated sentence by stating reasons, ${ }^{12} 4$ ) it provides review by a higher body to bring into compliance sentences impermissibly outside the guideline range. ${ }^{13}$

The Minnesota Guidelines divide facts into two categories, facts about the crime and facts about the criminal, and establish scales for each set. One scale ranks the seriousness of the crime; ${ }^{14}$ the other ranks the criminal history of the offender. ${ }^{15}$ Each serves as one of the two axes of the sentencing grid. ${ }^{16}$

has been changed by the Sentencing Reform Act of 1984, Pub. L. No. 98-473, §§ 211-39, 98 Stat. 1987 (codified in scattered sections of U.S.C.). The Act eliminates parole and sets up a federal sentencing commission charged with developing and promulgating a set of federal sentencing guidelines which federal judges must apply.

8. See Minn. Stat. AnN. $§ 244.09$ (West Supp. 1985) (establishing sentencing commission); id. at Subd. 12 (providing for adoption of guidelines in absence of legislative action); id. at Ch. 244-app. (guidelines and commentary).

9. See supra note 6 .

10. Minn. Stat. ANN. $\S 244.09$, Subd. 5(2) (West Supp. 1985) (sentence grid to be based on "appropriate combination of reasonable offense and offender characteristics").

11. Id.

12. Id. at $\$ 244.10$, Subd. 2 .

13. Id. at $\S 244.11$.

14. Id. at Ch. 244-app. (West Supp. 1985) (guidelines and commentary) (Offense Severity).

15. Id. (Criminal History).

16. Id. (reproduced on facing page). 


\section{Unreliable Factfinding and Sentencing}

\section{SENTENCING GUIDELINES GRID}

Presumptive Sentence Lengths in Months

Italicized numbers within the grid denote the range within which a judge may sentence without the sentence being deemed a departure.

CRIMINAL HISTORY SCORE

\begin{tabular}{|c|c|c|c|c|c|c|c|}
\hline \multirow[b]{2}{*}{$\begin{array}{l}\text { SEVERITY LEVELS OF } \\
\text { CONVCTKON OFFENSE }\end{array}$} & \multicolumn{7}{|c|}{ 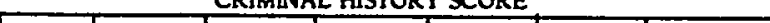 } \\
\hline & 0 & 1 & 2 & 3 & 4 & 5 & 6 or more \\
\hline $\begin{array}{l}\text { Unauthorized Use of } \\
\text { Motor Vehicle } \\
\text { Possession of Marifuana }\end{array}$ & $12 *$ & $12 *$ & $12 *$ & 15 & 18 & 21 & 24 \\
\hline $\begin{array}{l}\text { Theft Related Crimes } \\
\text { (\$150-\$2500) } \\
\text { Sale of Marifuana }\end{array}$ & $12 *$ & $12 *$ & 14 & 17 & 20 & 23 & $\begin{array}{c}27 \\
25-29\end{array}$ \\
\hline Theft Crimes (\$150-\$2500) III & $12 *$ & 13 & 16 & 19 & $\stackrel{22}{2.1-23}$ & $\begin{array}{c}27 \\
25-29\end{array}$ & $\begin{array}{c}32 \\
30-34\end{array}$ \\
\hline $\begin{array}{l}\text { Burglary - Felony Intent } \\
\text { Receiving Stolen Goods } \\
\quad(\$ 150-\$ 2500)\end{array}$ & * $12 *$ & 15 & 18 & 21 & $\begin{array}{c}25 \\
24-26\end{array}$ & $\begin{array}{c}32 \\
30-34\end{array}$ & $\stackrel{41}{37-45}$ \\
\hline Simple Robbery & 18 & 23 & 27 & $\begin{array}{c}30 \\
29-31\end{array}$ & 38 & $\begin{array}{c}46 \\
43-49\end{array}$ & $50-58$ \\
\hline Assault, 2nd Degree & 21 & 26 & 30 & $\begin{array}{c}34 \\
33-35\end{array}$ & $\begin{array}{c}44 \\
42-46\end{array}$ & $\begin{array}{c}54 \\
50-58\end{array}$ & $\begin{array}{c}65 \\
60-70\end{array}$ \\
\hline Aggravated Robbery & $\begin{array}{c}24 \\
23-25\end{array}$ & 32 & $\begin{array}{l}41 \\
38-44\end{array}$ & $\begin{array}{c}49 \\
45-53\end{array}$ & $\begin{array}{c}65 \\
60-70\end{array}$ & $\begin{array}{c}81 \\
75-87\end{array}$ & $\stackrel{97}{90-104}$ \\
\hline $\begin{array}{l}\text { Assault, Ist Degree } \\
\text { Criminal Sexual Condiut, vII } \\
\text { Ist Degree }\end{array}$ & $\begin{array}{c}43 \\
41-45\end{array}$ & 50 & $\begin{array}{c}65 \\
60-70\end{array}$ & $\begin{array}{c}76 \\
71-81\end{array}$ & $\begin{array}{c}95 \\
89-101\end{array}$ & $\begin{array}{c}113 \\
106-120\end{array}$ & $\begin{array}{c}132 \\
124-140\end{array}$ \\
\hline Murder, 3rd Degree & $\begin{array}{c}97 \\
94-100\end{array}$ & $\stackrel{119}{116-122}$ & $\stackrel{127}{124-130}$ & $\begin{array}{c}149 \\
143-155\end{array}$ & $\begin{array}{c}176 \\
168-184\end{array}$ & $\begin{array}{c}205 \\
195-215\end{array}$ & $\begin{array}{c}230 \\
218-242\end{array}$ \\
\hline Aurder, 2nd Degree & $\begin{array}{c}116 \\
111-121\end{array}$ & $\begin{array}{c}140 \\
133-147\end{array}$ & $\begin{array}{c}162 \\
153-171\end{array}$ & $\begin{array}{c}203 \\
192-214\end{array}$ & $\begin{array}{c}243 \\
231-255\end{array}$ & $\begin{array}{c}284 \\
270-298\end{array}$ & $\begin{array}{c}324 \\
309-339\end{array}$ \\
\hline
\end{tabular}

1st Degree Murder is excluded from the guidelines by law and continues to have a mandatory lifè sentence.

*one year and one day 
In devising the "Offense Severity" scale, the Minnesota Guideline Commission ranked crimes from most to least serious, divided the list into a series of categories (or "bands"), and assigned a number to each band. ${ }^{17}$ This ranking and categorization in effect defined the facts about the offense that are relevant to the sentence. ${ }^{18}$

Similarly, the Commission created a "Criminal History" scale. It was not the aim of sentencing guidelines to eliminate the individualization of sentences, but to ensure that the individualization is consistent from judge to judge. (That is, facts about the offender ought to matter in individualization, not facts about the judge.) Accordingly, the Minnesota Guidelines established a numerical scale to quantify the offender's criminal past. To calculate an offender's criminal history "score," the sentencer adds one point for each prior felony conviction, ${ }^{19}$ one point if the offender was on probation or parole at the time of the offense, ${ }^{20}$ one-half point for each prior gross misdemeanor conviction, ${ }^{21}$ and one-quarter point for each prior misdemeanor conviction. ${ }^{22}$ Theoretically, an offender score could include a much broader range of facts. For instance, the United States Parole Guidelines-which work on the same general principle as the Minnesota grid-include factors such as the offender's age at the time of the offense and any history of heroin or opiate dependency. ${ }^{23}$

After determining the crime's Severity Category (a factual determination) and the offender's Criminal History Score (another factual determination), the sentencer draws a line across from the vertical axis and down from the horizontal axis to the box in which the two lines intersect. That

17. See D. PARent, supra note 7, at ch. 4, pp. 8-16.

18. These facts do not always track the statutory definitions of crimes. For instance, the Minnesota Guidelines place kidnapping when a victim suffers great bodily harm in a higher severity band than kidnapping when the victim is released unharmed, but in an unsafe place, MinN. STAt. ANN. Ch. 244-app. (West Supp. 1985) (Minnesota Sentencing Guidelines \& Commentary) (felonies), even though an offender who does either of these things meets the elements of being legally guilty of the single crime of kidnapping, MinN. STAT. ANN. § 609.25(1) (West. 1964 \& Supp. 1986) (acts constituting kidnapping), and even though the legislature has authorized the same maximum sentence in both circumstances, id. at $\S 609.25(2)(2)$. Similarly, the U.S. Parole Guidelines place those who use the mails to retail child pornography in a lower offense severity band than those who wholesale, 28 C.F.R. § 2.20 ch. 11(D) (1984) (Severity Index), although the wholesale/retail distinction is irrelevant to guilt, see 18 U.S.C. $§ 2252$ (1982). The New York Guideline Committee also divided crimes into finer bands than current law provides, and recommended to the legislature that it amend the penal law to match the newly drawn bands. See N.Y. GUIDELINE REPORT, supra note 7, at 6-7, 37-38.

19. Minn. Stat. Ann. Ch. 244-app. (West Supp. 1985) (Sentencing Guidelines \& Commentary) (Criminal History).

20. Id.

21. Id.

22. Id. Under certain circumstances, juvenile convictions are scored as well. Id.

23. See 28 G.F.R. § 2.20, at 101 (1985) (Salient Factor Score chart). 
box contains a narrow range of months, and the statute directs the judge to impose a sentence within that range. ${ }^{24}$

To allow flexibility in unusual cases, Minnesota permits a judge to depart from the range in the box. To do so, the judge either must find that a "departure factor" listed by the guidelines exists, ${ }^{25}$ or must identify an unlisted factor that demonstrates that the sentence in the box is inappropriate or inequitable. ${ }^{26}$ In either event, the finding must be placed on the record. ${ }^{27}$ Any system of departures, however, would threaten to undermine the system unless policed to ensure that the departures, like the presumptive sentences, were regular. Thus, in a pronounced break with sentencing practices of the past, the Minnesota Guidelines allow appellate review of sentences, ${ }^{28}$ which enables the higher courts to develop a common law of departures. All sentences have thus become standardized-those that do not depart by statute, and those that do by emerging case law. No longer can one judge apply a different, unwritten sentencing code than a brother or sister judge across the corridor.

The guiding principle of sentencing grids, then, is that they yield a specific sentence when applied to a specific factual situation. Indeed, this must be true of any reform seeking to curtail judges' sentencing discretion by making them follow rules. As Arthur Leff has said, "it is a fundamental tenet of most systems of justice that identical things be treated identically; that is what 'following a rule' means." ${ }^{29}$ Although guidelines still might allow some disparity-because they put a small range instead of a single number in a box-the notion of equal treatment of factually identical cases is at their core. ${ }^{30}$

24. Minn. Stat. AnN. Ch. 244-app. (West Supp. 1985) (Departures from the Guidelines) ("The judge shall utilize the presumptive sentence provided in the sentencing guidelines unless the individual case involves substantial and compelling circumstances.").

25. For instance, the Guidelines explicitly allow a judge to depart from the box upon finding: "The offender played a minor or passive role in the crime...."Id.

26. Id.

27. Id.

28. Minn. Stat. ANn. § 244.11. (West Supp. 1985).

29. Leff, The Leff Dictionary of Law: A Fragment, 94 YALE L. J. 1855, 2016 (1985) (emphasis in original) (from definition of "analogy"). Of course, before they can apply this rule, decisionmakers need to answer the difficult question, "When is something so like something else that it should be treated the same, or so unlike that it should not[?]" Id. (emphasis in original). One of the main points of sentencing guidelines is that they make this decision for judges, unlike traditional schemes where each judge decides for himself.

30. Providing a small range instead of a single number actually can even promote the principle of consistency. Because "it is in fact never the case that all other things are equal," id. at 2235 (from definition of "caeteris paribus") (emphasis in original), it might be counter-productive to require a single number. By providing a small range, the grid allows judges to impose slightly different sentences in cases which are slightly different. 


\section{The Jerome Frank Problem of Slippery Facts}

To truly eliminate disparity, sentencing reformers must standardize not only substantive sentencing law, but also the procedures that bring to the sentencer the facts to which that law will be applied. Jerome Frank pointed out over a half century ago that judicial decisions (D) are a function of substantive rules of law (R) as applied to the facts of individual cases $(\mathrm{F}){ }^{31}$ Frank expressed the relationship in an equation: ${ }^{32}$

$$
\mathrm{F} \times \mathrm{R}=\mathrm{D}
$$

In striving to eliminate disparity, guideline authors have standardized the $R$, the substantive rules of sentencing. Decisions will not, however, be regular or predictable unless the F's are being established through reliable procedures, procedures which will ensure that cases that are factually similar are being described as similar to whomever is applying the R. ${ }^{33}$

In the rest of this essay, I will use examples from the literature and from the ongoing Guggenheim Sentencing Project at Yale ${ }^{34}$ to demonstrate that the procedures that develop the facts for sentencers are often unreliable and erratic.s5

31. Frank, What Courts Do In Fact, 26 ILL. L. Rev. 645, 649 (1932).

32. Id. at 649; J. Frank, Courts on Trial 14 (1950).

33. That sentencing guidelines are sometimes characterized as "computerized sentencing" helps demonstrate this point. There is an acronym among computer programers: GIGO. It stands for "Garbage In, Garbage Out," which means that it makes no difference how good a computer program is if you feed bad data into it. See Computer Science \& Eng'g Bd., Nat'l Academy of Sciences, Databanks in a Free Society: Computers, Record-Keeping and Privacy 300 (1972). Professor John Coffee has made this observation with regard to sentencing in two articles. Coffec, Repressed Issues of Sentencing: Accountability, Predictability, and Equality in the Era of the Sentencing Commission, 66 Geo. L. J. 975, 986-87 (1978); Coffee, The Future of Sentencing Reform: Emerging Legal Issues in the Individualization of Justice, 73 Mrck. L. Rev. 1361, 1374 (1975). Coffee seems particularly concerned with probation officers including in the Presentence Investigation Report (PSI) unverified information about the offender gleaned from databanks: computerized educational records, juvenile records, arrest records, conviction records, police intelligence reports, and the like. Alone, these problems pose formidible difficulties for sentencing guidelines. Id. at 1376-91. The problem of bad information, though, is not only that bad information can make its way into a PSI from computerized files elsewhere, but that the procedures and customs at nearly every stage of the criminal process are so lax that they virtually ensure that like cases will not be described to the sentencer as alike.

34. For the last three years, the Daniel and Florence Guggenheim Criminal Justice Program at the Yale Law School has been examining the problems of sentencing through close study of a small number of trial judges from different jurisdictions. The judges have undergone extensive interviews by members of the Yale Project, have been observed by students and faculty members while plea bargaining and sentencing in their home jurisdictions, and have participated in seminars with each other. Among its other data, the Project has so far produced a number of unpublished studies of different judges from Connecticut, Ohio, Massachusetts, New Jersey, New York, and Washington, D.C., from which I will draw examples.

35. The rest of the essay is not meant to catalogue every step in the criminal process that bears on factfinding at sentencing (because virtually every step will), but only to discuss a few topics which demonstrate the kinds of factfinding issues that commissions framing sentencing guidelines must face. 


\section{A. Developing the Facts at Trials and at Guilty Pleas}

The overriding reality of today's criminal justice system is that the trial--society's model for getting at the truth $^{36}$-is used in only a fraction of criminal cases; the overwhelming majority of criminal convictions nationwide are entered by an offender's guilty plea. ${ }^{37}$ One of the characteristics of a trial is that it often fleshes out the particulars of an offense in the way that a plea allocution does not. At a trial, the prosecution must prove the defendant's guilt through real evidence and testimony. In the normal course of telling their stories, witnesses will relate their version of the incident in exacting detail, because a witness in a trial needs to demonstrate a command of the minute to prove the accuracy of his or her memory. ${ }^{38}$ In contrast, when pleading guilty, an offender need admit only the broad elements of the crime, and no witnesses rehearse the details of the offense for the court. ${ }^{39}$

36. Tehan v. United States ex rel. Shott, 382 U.S. 406, 416 (1966) ("The basic purpose of a trial is the determination of truth . . . ." ); Louisell, Criminal Discovery: Dilemma Real or Apparent?, 49 Cal.IF. L. Rev. 56, 97 (1961) (The "objective" of a criminal trial is "accurate fact ascertainment"). Of course, the trial also serves much wider purposes in our system of government, which may conflict with simple factfinding. For instance, factual accuracy at trial is sacrificed in the service of the Bill of Rights when the 4th Amendment excludes evidence seized without a valid warrant. And even the nature of the adversary system itself can impede the search for truth. "[T]ruth and victory are mutually incompatible for some considerable percentage of attorneys trying cases at any given time." Frankel, The Search for Truth: An Umpireal View, 123 U. PA. L. REv. 1031, 1037 (1975).

37. Bureau of Justice Statistics, U.S. Dep't of Justice, Report to the Nation on CRIMe and Justice 65 (1983) [hereinafter cited as RePORT TO THE NATION] (in selected jurisdictions in 1979 , guilty pleas ranged from a low in one jurisdiction of $81 \%$ to a high in another of $97 \%$ of all convictions) (citing unpublished study). See also N.Y. GuIDELINE REPORT, supra note 7, at 26-27 (in 1983, guilty pleas accounted for $92 \%$ of felony convictions in New York State).

38. Despite the relatively great amount of information considered during the course of a trial, the trial, of course, is by no means a perfect factfinding mechanism. Probably, there is no imaginable type of legal hearing that could always be objectively, historically accurate. As Jerome Frank has pointed out:

The facts themselves do not walk into court. The court has to guess what actually happened, basing its own fallible guess on fallible inferences made while listening to and watching fallible witnesses-sometimes lying, often mistaken, who frequently disagree with one another about what actually occurred outside the court-room-what happened, mind you, weeks or months or years before the case began.

Frank, supra note 31, at 650. See also J. FraNk, supra note 32, at 14-16. But acknowleding that some uncertainty will persist no matter how thorough the factfinding procedures is not to say that all factininding procedures are equal. It seems self-evident that the judge's "guess" at the truth will be a better educated guess after a hearing in which he has heard and seen witnesses telling their stories in detail (as in a trial) than after a hearing at which he has heard only a quick summary of the relevant events (as in a guilty plea).

39. See Newman \& NeMoyer, Issues of Propriety in Negotiated Justice, 47 DEN. L.J. 367, 398-99 (1970) (discussing gap between "formal words of charge" and rich variation of conduct which may underlie any given charge).

"[A]n express admission of guilt" is not the only way that an offender is permitted to enter a guilty plea. North Carolina v. Alford, 400 U.S. 25, 37 (1970). On the theory that the standard of legal guilt is sometimes "uncertain and elusive," id. at 33 (quoting McCoy v. United States, 124 U.S. App. D.C. $177,179,363$ F.2d 306, 308 (1966)), it is sufficient that an offender concede that there is a likelihood of conviction, see id. at 28 n.2, 37, and that the court conclude that there is a "strong factual basis for the plea," $i d$. at 38. Though it may be disturbing for other reasons that an offender is allowed to 
Of course, both after a trial and after a guilty plea, the sentencer will probably gather additional information relevant to sentencing, perhaps through a presentence report or counsel's submissions. ${ }^{40}$ But it is likely that some of the facts about the offense that would come out at trial will never reach the sentencer, and, even if they do, they will not always present themselves with the same vividness.

The extra information that a trial elicits can cut either way. In some cases the facts look better and in others they look worse. One of the judges studied by the Guggenheim Project gave a hypothetical (based on a real case of his) to demonstrate how a trial can change the picture of a case that a judge develops during plea negotiations:

The defendant is accused of coming upon a 65 or 70-year-old woman. . . . The [prosecutor's] write-up reads, "He grabbed her pocketbook, he yanked it from her, she fell to the ground, broke her hip, injured her arm and he fled." Okay? And your immediate assumption in [trying to negotiate a plea bargain] is, "What a mean little rat to knock down that nice old lady and steal a pocketbook." . . . The defense counsel is usually at a loss at that point. He has not seen the old lady. He doesn't really have a great understanding of the event. His client gives him a particular version [which] he finds hard to believe, so he's not terribly convincing in persuading you .... When you get to trial, what you discover is that he reached out to this woman, who indeed is 70 but looks 50, and grabbed her pocketbook, and she said, "Hey you son-of-a-bitch, what are you doing," and she grabbed it back. He then pulled her pocketbook again and she tripped over a crack in the sidewalk and fell down, and as she fell she hit a fire hydrant and broke her hip. Your entire perspective with respect to that defendant has changed ....41

During this hypothetical plea negotiation, the judge had made two implicit "findings" of fact: first, that the victim was frail; second, that the offender gratuitously threw her to the ground." At trial, both "findings" are proven false. The victim is vigorous, and she was not viciously

plead guilty while simultaneously maintaining innocence, it makes little difference to the argument here. Under Alford, the offender need concede that only those facts which establish the elements of the offense would likely be proved. So there is neither admission to "sentencing facts" nor a judgment that there is a likelihood that they would be proved.

40. See infra text accompanying notes 74-102.

41. Justice Jeffrey Atlas, Remarks to Guggenheim Sentencing Project, in New Haven (Oct. 12, 1984).

42. Under a guideline system, either of these findings could justify a departure from a presumptive sentence. For instance, the proposed New York Guidelines allow an upward departure either when, "The defendant's conduct during the commission of the offense manifested deliberate cruelty to the victim," N.Y. GuIDEline REPORT, supra note 7, at 88 (Aggravating Factors), or when, "The defendant knew, or should have known, that the victim was particularly vulnerable because of age [or] infirmity ...," id. 
knocked down, but she tripped during a struggle. To this judge, the difference in the two descriptions of the same event would probably have meant the difference between brief incarceration and probation. ${ }^{43}$

On the other hand, trials can bring home the brutality of some cases in a way that no plea discussion ever could. When witnesses detail the brutal circumstances of the crime and when the victim testifies about the terror he suffered, new "facts" about the gravity of the offense are put before the sentencer. ${ }^{4}$

\section{B. Factfinding Accompanying Guilty Pleas}

When there is a trial, the trial itself is not the only source of information that the judge has before sentencing. A number of other channels-such as plea conferences, presentence reports, and various hearings-supplement the judge's knowledge of the facts. When there is no

43. Remarks of Justice Atlas, supra note 41. Justice Atlas also told the project that differences in the ways that cases looked before and after trial would, when he was a trial lawyer, sometimes dictate defense strategy: "There were times when I tried cases because . . . although I knew my client was going to be convicted that the judge would be persuaded not to send him to jail after the trial. . . ." Id. Accord Kuh, Trial Techniques: Defense Counsel's Role in Sentencing, 14 CRIM. L. BulL. 433, 436 n.5 (1978) [hereinafter cited as Defense Counsel's Role]. Kuh says:

Sometimes, a trial can be helpful, even if there is little chance of acquittal, in constituting a full dramatic living presentence report of sorts; it may assist the court in recognizing that the defendant's intent was not as heinous as the mere existence of the plea of guilty-in isolation-may indicate.

44. See, e.g., O. Sohmer, Portrait in Profile: A Study of the Sentencing Practice of Judge Robert J. Callahan 44 (Mar. 22, 1985) [hereinafter cited as "Callahan Profile"] (unpublished manuscript available from Guggenheim Sentencing Project):

When sentencing on a plea, the Judge is basing his decision on the statements of the lawyers, the cold legal dissection of the elements of a criminal statute, and sometimes the reaction of the victim as related in the PSI. But after a trial, the Judge has seen the people involved. He has watched the defendant for several days or even weeks and has heard him speak, perhaps. He has seen the victim and heard testimony of the trauma and terror of the crime. That does not come from the file.

See also Comment, The Influence of the Defendant's Plea on Judicial Determination of Sentence, 66 YALE L.J. 204, 218-19 (1956) (guilty plea "may contribute" to shorter sentence because "brutal circumstances" may neither be emphasized by prosecutor nor "vividly recounted" at trial). Some defense attorneys will use the guiliy plea as a technique for avoiding damaging facts:

Under the pressure of a heavy, time-consuming caseload, the prosecutor may easily be seduced at an early stage of the proceedings, before such facts are more fully developed, by the offer of a quick guilty plea in exchange for a light sentence, only to discover too late that the offense, or the offender, was far more serious than originally thought.

Enker, Perspectives on Plea Bargaining, in TAsk Force ON THE Administration of Justice, President's Commission on LAW ENforcement and Administration of Justice, Task FORCE REPORT: The CourTS app. A, at 108, 110-11 (1967). Although it would be difficult to fill in facts that are absolutely missing from the case during plea negotiations, some judges try to compensate for the lack of vividness: " 'When I look at a defendant,' says Judge Rothwax, 'I try not to think of him as he looks in court, well-dressed, polite. I try to picture him as he threw the old lady down the stairway.' " P. Pope, Sentencing Profile of [Justice] Harold J. Rothwax 29 (Sept. 1984) [hereinafter cited as "Rothwax Profile"] (unpublished manuscript available from Guggenheim Sentencing Project). 
trial, however, these "supplementary" sources become the only procedures bringing the facts to the sentencer.

\section{Pre-Negotiation Factual Development}

In the absence of a trial, even those procedures far removed from the adjudication of guilt take on heightened importance. For instance, in jurisdictions in which a case is passed from lawyer to lawyer as it progresses through the various stages (both prosecutors' and public defenders' offices sometimes follow this pattern), ${ }^{45}$ it can make an enormous difference who conducts the original interviews of the witnesses, victims, and police officers. If the interviewer-who, depending on the place and the crime, may be a junior attorney, a senior attorney, or a layperson ${ }^{46}$-fails to elicit a salient piece of information or forgets to write it in the file, it may never reach the sentencer. ${ }^{47}$

The extraordinary lack of diligence that some attorneys demonstrate can make the problem of information development and communication even more acute. The literature reports, for instance, that many public defenders interview their clients for the first time with an eye not toward developing the facts of the case, but toward trying to figure out what charge the defendant is willing to "cop out" (plead guilty) to. ${ }^{48}$ Because

45. Graham \& Letwin, The Preliminary Hearings in Los Angeles: Some Field Findings and Legal-Policy Observations, 18 U.C.L.A. L. REv. 635, 645 (1971) (case passed from prosecutor to prosecutor like baton in relay race); Rothwax Profile, supra note 44, at 31 (prosecutor who investigates case usually does not negotiate plea); Sudnow, Normal Crimes: Sociological Features of the Penal Code in a Public Defender Office, 12 Social Problems 255, 265-66 (1965) ("Over the course of his proceedings, a defendant will have several attorneys ... . [T] he file is relied upon to furnish all the [essential] information .....").

46. In Manhattan, rookie prosecutors are broken in on misdemeanors while the more seasoned work in the Supreme Court on felonies. Rothwax Profile, supra note 44, at 98 n.17. In the Bronx, particularly experienced prosecutors are assigned to "major offenses." Merola, The Major Offense Bureau: A Blueprint for Effective Prosecution of Career Criminals, 11 THE Prosecuror 8, 9 (1975). In Nashville, Tennessee, non-legal clerks tutored by the D.A.'s office have conducted the initial examination of the arresting officer, and usually the D.A. has no further discussion with the officer about the case. See Domash, Stromatt, Carr, Schnelle, Kirchner \& Shriver, Criminal Case Preparation: A Police-Prosecution Cooperative Effort, 14 THe ProsecuToR 417, 418 (1979).

47. "[I]f [the deputy prosecutor conducting the original interview] fails to record the existence of a piece of evidence, another deputy will not be able to use it in the prosecution and may in good faith reply to the defense attorney either in discovery or in negotiations that such evidence does not exist. As a result the defendant may choose a course of conduct, such as a guilty plea or a demand for a jury trial, in ignorance of the true facts. The same may be true of bail motions, motions to suppress and even sentencing." Graham \& Letwin, supra note 45, at 645.

48. J. Casper, American Criminal. Justice: The Defendant's Perspective 106-07 (1972). Some public defenders suffer such enormous caseloads that they may spend less than 10 minutes total with a client before pleading him guilty. Id. at 106. Casper reports: "among the first words uttered by [the public defender when meeting a client] were: 'I can get you 2 if you plead guilty.' "Id. at 106. Accord Sudnow, supra note 45, at 266-70 (1965) (P.D.s' interviews of defendants not conducted to establish detailed facts or to wage a defense, but to determine that case is suitable for rapid guilty plea disposition). This approach to criminal "defense" work obviously precludes any possibility of an independent investigation of the facts. And where a lawyer solely relies on an initial interview with a client for the facts, he is unlikely to get even the client's complete version; in the best of 
"factfinding" at a guilty plea often relies heavily on investigation and representation by counsel, such a cursory development of the case virtually assures that cases will not be described accurately to the sentencer, and, therefore, that like cases will not be perceived and treated by the sentencer as alike.

After the initial interviews, attorneys engage in discovery about the case. This stage may constitute the most crucial "factfinding" of the process, because the information developed here will be the grist for the plea discussions. Facts never discovered will never be discussed and cannot figure into the plea bargain. Thus the procedures under which discovery takes place can bear directly on the final sentence imposed.

Pretrial criminal discovery laws vary enormously from state to state. For instance, whereas Louisiana explicitly does not authorize defense discovery of statements by prospective witnesses, ${ }^{49}$ Alaska requires the prosecutor to disclose statements made by anyone "known by the government to have knowledge of relevant facts," ${ }^{200}$ and Florida not only requires prosecutors to disclose statements, but also allows the defendant to depose potential witnesses. ${ }^{11}$ Each of these procedures will put different facts in the hands of the defense for the plea negotiations, or, put another way, each will produce different descriptions of the same case. If guidelines are to reduce sentence disparity, they must be supported by discovery procedures that find facts fully, accurately, and consistently.

But one does not learn the full story about pre-plea discovery simply by looking at statutory provisions; local custom may "rewrite" the rules on the books. For instance, in some towns in Connecticut, the defense counsel gets only a quick look at the prosecutor's file when he and the prosecutor go over it briefly together in the prosecutor's office. ${ }^{52}$ In other towns, defense counsel are actually permitted to take the files home overnight. ${ }^{53}$ There are even discovery variations from lawyer to lawyer. Some prosecutors are more willing to open their files than others, ${ }^{54}$ and some prosecu-

circumstances, “A lawyer cannot accept a client's first account as complete or accurate." H. FrEEMAN \& H. Weihofen, Clinical Law Training: Interviewing and Counseling 30 (1972).

Private defense lawyers can be in even worse positions, as their "professional livelihood depends on . . not trying many cases." L. WeInReB, Denial of Justice 73 (1977) (emphasis in original). See also Alschuler, The Defense Attorney's Role in Plea Bargaining, 84 YALE L.J. 1179, 1180 (1975) (even conscientious attorneys are led by plea bargaining to work against clients' interest); Comment, In Search of the Adversary System-The Cooperative Practices of Private Criminal Defense Attorneys, 50 TEx. L. REv. 60, 61 (1971) [hereinafter cited as Private Lawyers] ("Fee limitations necessitate abbreviated defenses, just as do inadequate budgets for a public agency.").

49. LA. Code Crim. Proc. AnN. art. 723 (West 1981).

50. Alaska R. Crim. P. 16(b)(1)(i).

51. Fla. R. Crim. P. 3.220(a)(1)(ii), (d).

52. M. Heumann, Plea Bargaining 35 (1978) (discussing courts of limited felony jurisdiction).

53. Id.

54. See Private Lawyers, supra note 48 , at 70. 
tors play favorites with defense counsel, opening files only to those with whom they have good relationships. ${ }^{\mathrm{ss}}$ All in all, different attorneys, even operating under the same formal discovery rules, will get different pictures of a case.

\section{Factual Development at the Plea Negotiation}

The paradigm of the plea bargain is that a defendant pleads guilty in exchange for a "break" on the sentence. For instance, one of the Guggenheim judges gives a plea discount by awarding one-third off the sentence expected for an offender who is convicted at trial. ${ }^{56}$ Dispensed this way, the plea discount is a part of Jerome Frank's $R$, and the fact of the guilty plea part of the F: If guilty plea then award discount. Putting aside whether this kind of "break" is wise or just (either under a traditional sentencing scheme or a guideline regime), it creates no disparity as long as it is awarded even-handedly. ${ }^{.7}$

55. See id. at 68-70; M. HeUmanN, supra note 52, at 63 (prosecutor punishes lawyer who files pretrial motions in case by denying access to files in other cases). See also id. at 183 n.36 ("the state's attorney might be more willing to share his files with the cooperative attorney . . .").

56. M. Berkman, Profile of Judge Frank J. Kinney, Jr. 23 (May 5, 1986) [hereinafter cited as "Kinney Profile"] (unpublished manuscript on file with Guggenheim Sentencing Project). Plea discounts are not always given so forthrightly, and, in some places, judges do not grant them at all; prosecutors do by dismissing or reducing charges. This "charge bargaining" lowers the ceiling on the judge's sentencing range, reducing the offender's "exposure." Whether a sentence is cut through the exercise of sentencing discretion (by a judge) or the exercise of charging discretion (by a prosecutor) is analytically irrelevant. The point is that both judges and prosecutors grant discounts off of what they believe to be the real, historical offense. One of the rules of sentencing is that the offender's sentence is reduced when a fact of the case is that it was disposed of by guilty plea.

57. Ensuring even-handed award of discounts becomes a technical issue. For instance, where judges themselves offer the discount, it could be mandated that the discount be a specific proportion of the sentence. See Note, Restructuring the Plea Bargain, 82 Yale L.J. 286, 301 (1972) (proposing fixed-rate plea discount). It is also technically possible to vary the size of the discount to serve any special concerns of judicial administration. For instance, one of the Guggenheim judges consciously gives bigger plea discounts when he has a particularly heavy case backlog. Another gives bigger discounts when there are provability problems with the case. If society decides to retain these practices, it is easy enough to make provability and caseload relevant factors in the size of the guideline's plea discount.

When prosecutors grant the discount instead of judges, there must likewise be regularization, lest judicial sentencing discretion simply be passed backwards. See Alschuler, Sentencing Reform and Prosecutorial Power: A Critique of Recent Proposals for "Fixed" and "Presumptive" Sentencing, 126 U. PA. L. REv. 550, 563-72 (1978). One way of preventing the mere relocation of disparitycausing discretion is to create prosecutorial guidelines to go with sentencing guidelines. See Schulhofer, Due Process of Sentencing, 128 U. PA. L. REv. 733, 787-98 (1980) (advocating guidelines for plea bargaining). For example, Washington has already accompanied its sentencing grid with nonbinding prosecutorial guidelines. WASH. REv. CODE ANN. $\$ \S 9.94 A .430-.460$ (West Supp. 1986) (Recommended Prosecuting Standards for Charging and Plea Dispositions).

In addition, the very enactment of sentencing guidelines-even without explicit prosecutorial guidelines-can be read as an empowerment of and mandate to judges to police prosecutorial charge bargaining. Although the prosecutor has generally been thought to have a monopoly in charging decisions, the charge bargain is the frontier at which the prosecutor's decision to charge meets the judge's decision to sentence. United States v. Miller, 722 F.2d 562, 564 (9th Cir. 1983) ("When a plea bargain is placed before court, the necessary interplay between charging and sentencing decisions becomes manifest."). Several circuits have, under traditional sentencing schemes, already adopted a 
The plea bargain can, however, affect sentence disparity in another way. The process of the plea negotiation itself may tend to misdescribe the facts from which the discount will be taken. To avoid disparity, the "break" must be applied to an accurate factual predicate.

\section{a. The Sentence Bargain}

One variety of the plea bargain is the sentence bargain, in which an offender pleads guilty in exchange for a promise that a particular sentence will be imposed. At the time of the guilty plea, the judge puts the promised sentence on the record, and that promise must be kept subject to the same restriction that applies to all promises put on the record when a defendant tenders a guilty plea: if the state does not keep the promise, the defendant may withdraw the plea. ${ }^{58}$ Because a sentence bargain requires a judge to ratify the number that opposing counsel have worked out, the crucial question is how much the judge knows about the facts of the case when he approves the bargain, because, for all practical purposes, approval is the imposition of a sentence.

The way that judges learn of the facts varies greatly. For instance, one judge studied by the Guggenheim Project conducts all of his sentence negotiations at the bench, off the record. ${ }^{58}$ The prosecutor-generally not the prosecutor who investigated the case ${ }^{60}$-hands the judge a sheet from a yellow legal pad on which, in a few paragraphs, the prosecutor who did do the investigation has written out the state's version of the offense. ${ }^{61}$ In the course of the next few minutes, the judge, the defense counsel, and the prosecutor try to agree on the appropriate sentence based on the description on the yellow sheet, the defendant's prior record, and any information

rule which allows a judge to reject a charge bargain when the bargain intrudes too deeply on the sentencing authority of the trial judge. See, e.g., United States v. Ammidown, 497 F.2d 615, 622 (D.C. Cir. 1973) ("protection of the sentencing authority reserved to the judge" may sometimes justify refusing plea bargain); United States v. Bean, 564 F.2d 700, 704 (5th Cir. 1977) (that bargain would result in "too light a sentence" is "sound reason" to reject agreement); United States v. Ocanas, 628 F.2d 353, 358 (5th Cir. 1980), cert. denied, 451 U.S. 984 (1981) (same) (dicta). In a system in which statutory punishment ranges are broad and overlapping, a judge's scope will only infrequently be significantly infringed. In Ammidown, for example, the court ruled that the difference in possible sentences was too slight to warrant upsetting the bargain. In a guideline system, however, reducing charges will actually change the box on the grid. Thus, to protect their roles as authoritative sentencers, United States v. Escobar Noble, 653 F.2d 34, 36-37 (1st Cir. 1981) ("It is the peculiar function of the court, not the prosecutor, to say the last word about the justice of a sentence."), courts can read the very enactment of guidelines as a command to ensure that the discounts granted by prosecutors are regular. See also A. Goldstein, The Passive Judiciary: Prosecutorial DiscreTION AND THE GUILTy PLEA (1981) (advocating judicial fashioning of common law of prosecutorial discretion).

58. Santobello v. New York, 404 U.S. 257 (1971).

59. Rothwax Profile, supra note 44, at 33.

60. Id. at 31 .

61. Id. at 28,33 . 
that defense counsel might add. ${ }^{62}$ The entire negotiation takes place out of earshot of the defendant, who is seated at the defense table some 20 feet away. When the negotiation is complete, defense counsel steps over to the defendant to relay the terms of the deal. If the deal is acceptable, the defendant pleads guilty on the spot. The judge puts the negotiated sentence on the record as part of the plea, orders the probation department to prepare a PSI (which is fairly inconsequential at this stage), and sets a date at which the sentence will actually be imposed. In the course of a routine day, the judge will try to negotiate sentences in 40 to 80 felony cases, roughly a defendant every six minutes. ${ }^{\text {ss }}$

Another of the judges studied by the Guggenheim Project also deals in sentence bargains, but the negotiating customs in his jurisdiction are very different. ${ }^{64}$ The negotiating is done in the judge's chambers with a group of attorneys present, but no defendants. ${ }^{65} \mathrm{~A}$ defense counsel or state's attorney may sit through several other lawyers' quasi-public negotiations before the judge gets to his cases. The judge listens to the lawyers' versions of the case, and then gives his estimate of its "worth," sometimes pointing to facts in the case which demonstrate his "going rates," thus using negotiations to school less experienced lawyers. ${ }^{68}$

A third judge studied by the Project conducted plea negotiations more casually, sometimes discussing plea dispositions in chambers when only one of the attorneys was present, and piecing together a version of the events from the attorneys' separate accounts. ${ }^{67}$ This judge tried to take special care to make sure that he repeated to each attorney everything that the other had told him, and, unlike the first two judges, put every fact of importance on the record at the sentencing. ${ }^{\text {B }}$

None of the differences in these practices are dictated by the law of the jurisdiction. Each is a result of habit, local custom, or the style of the judge. And it is easy to see how the differences can lead to deeper or shallower discussion of the facts and leave more or less room for poor communication and mistakes.

\section{b. The Charge Bargain}

Another variety of the plea bargain is the charge bargain. In a charge bargain, the judge does not commit himself to a specific sentence before

62. Id. at 33-35. Usually, the D.A.'s request for a particular sentence will also be in the file. Id. at $29-30,33$.

63. Id. at 16.

64. Kinney Profile, supra note 56 , at 25 .

65. Id. at $25-28$.

66. Id.

67. Proceedings of Guggenheim Sentencing Project, in New Haven (Mar. 30, 1985).

68. Id. 


\section{Unreliable Factfinding and Sentencing}

the plea is entered. Instead of dealing with the judge, the defense deals with the prosecutor. If the prosecutor agrees to drop some charges, the total number of years that the judge can impose-the defendant's "exposure"-is reduced. ${ }^{69}$ The judge may not participate in negotiations at all, ${ }^{70}$ and, therefore, may be largely ignorant of the facts of the case before going into the plea hearing.

At the plea hearing, the judge must develop at least some of the facts of the case. ${ }^{71}$ However, the set of facts necessary to support a conviction (guilt facts) is much smaller than the set which the judge may use to impose sentence (sentencing facts). ${ }^{72}$ For instance, if three offenders plead guilty to conspiracy to import heroin into the country, it is enough, for the purpose of their guilty plea, that each admits to agreeing to carry out the importation. Yet in order to assess culpability and levy sentence, the judge would want to know that one was the financier, the other the captain of the freighter that would carry the drugs, and the third merely a deckhand. Therefore, to impose a sentence after a guilty plea has been induced by a charge bargain, most judges will turn to various post-conviction factfinding tools.

69. Charge bargaining will have one of two effects. It may actually cut into the sentence that the judge would impose. For instance, consider a case where the top charge carries 25 years, and the prosecutor allows the defendant to plead out to a charge which carries a maximum of 15 years. If, after learning the facts, the judge wishes to impose a 20 -year sentence, his sentence has actually been affected by the charge bargain; it has been reduced by 5 years. On the other hand, if he wishes to impose a 10-year sentence, then the bargain has not affected the sentence at all; it is irrelevant whether the maximum is 25 or 15 years. See M. Heumann, stpra note 52, at 42 ("Charges can be dropped without reducing the realistic range of years within which the defendant will be sentenced."). If there is a problem here it is not that the plea bargain has upset regularity in sentencing, but that the defendant may have been duped into thinking that he was getting something for his guilty plea that, in fact, he already had. See W. Rhodes, Plea Bargaining: Who Gains? Who Loses? 57 (1978) ("Contrary to expectations, sentence concessions were not routinely awarded to suspects entering guilty pleas").

70. Some jurisdictions unequivocally forbid judges to participate in negotiations. See, e.g., United States v. Werker, 535 F.2d 198, 205 (2d Cir. 1976) ("[W]e conclude that fair and expeditious disposition of criminal cases is best achieved by the [federal] trial judge completely abstaining from any participation in any discussions or communications regarding sentence . . . ."); FED. R. CRIM. P. $11(e)(1)$ ("The court shall not participate in any such discussions").

71. See, e.g., FED. R. CRIM. P. 11(f) ("[T]he court should not enter a judgment upon [a guilty] plea without making such inquiry as shall satisfy it that there is a factual basis for the plea."); CoNN. R. CRIM. P. \$ 713 ("The judicial authority shall not accept a plea of guilty unless he is satisfied that there is a factual basis for the plea."); TENN. R. CRIM. P. 11(f) (same as federal rule); VT. R. CRIM. P. $11(f)$ (same); WASH. R. CRIM. P. 4.2(d) ("The court shall not enter a judgment upon a plea of guilty unless it is satisfied that there is a factual basis for the plea."). One of the Guggenheim judges carefully reviews the notes he took at the guilty plea before going into the sentencing hearing, and mentions on the record that he has done so. E. Liebman, Sentencing Profile of Judge Frederick H. Weisberg 31 (Jan. 23, 1985) [hereinafter cited as "Weisberg Profile"] (unpublished manuscript on file with Guggenheim Project).

72. Almost 40 years ago, Williams v. New York, 337 U.S. 241 (1949), established that a sentencing judge could-indeed ought to-use information far beyond that which established the requisite elements of the offense. The "modern penological procedural policies" of individualizing punishment created a need for greater information about both the offense and the offender to impose a thoughtful sentence. Id. at 250 . Hence the gap between guilt facts and sentencing facts. 


\section{Factual Development After the Plea}

As should be plain from earlier discussions, after a sentence bargain, any post-conviction factfinding will largely be for naught. Unless the judge learns something important enough to upset the plea and start from scratch, ${ }^{73}$ the sentence negotiated is the sentence imposed. After a charge bargain, on the other hand, the judge must still arrive at a sentence; thus understanding the post-conviction procedures is vital to understanding factfinding at sentencing.

\section{a. The Presentence Investigation Report}

The first of these post-plea procedures is the Presentence Investigation Report (PSI), the document that the judge commissions after a guilty plea has been entered to inform the court about facts relevant to sentencing. ${ }^{74}$ Normally researched and written by a probation officer acting as an arm of the court, ${ }^{75}$ the PSI is likely to be the most complete written version of the offense that a judge will see. ${ }^{78}$

Like pre-plea discovery laws, state laws on the preparation of PSI's vary dramatically. Statutes range from forbidding a judge to sentence until a PSI has been prepared and delivered to court, ${ }^{77}$ to requiring a PSI on defendant's motion, ${ }^{78}$ to not providing for a PSI at all. ${ }^{78}$ But as with dis-

73. For instance, after a sentence bargain has been accepted by the court, Connecticut rules provide:

If the case is continued for sentencing, the judicial authority shall inform the defendant that a different sentence from that embodied in the plea agreement may be imposed on the receipt of new information ...., but that if such a sentence is imposed, the defendant will be allowed to withdraw his plea ....

CONN. R. CRIM. P. $\S 697$.

74. See Williams v. New York, 337 U.S. 241, 249-50 (1949) (discussing value to sentencing judge of information contained in PSI). For statutory authority for PSI's and what they may include, see, e.g., Fed. R. Crim. P. 32(c); N.Y. Crim. Proc. Law $\$ \S 390.20-.30$ (McKinney 1983 \& Supp. 1986); Mass. R. Crim. P. 28(d); Conn. Gen. Stat. § 54-91a(a), (c) (1985).

75. See, e.g., FED. R. CRIM. P. 32(c)(1) ("The probation service . . . shall make a presentence investigation . . . "); CoNN. GEN. STAT. \$ 54-91a(a) (1985) (probation officer writes report); MAss. R. CRIM. P. 28(d)(1) ("The probation officer shall inquire . . ."). But see Iowa CoDE ANN. \$ 901.2 (West Supp. 1985) (investigation conducted by branch of correctional services). For a historical explanation of why this task has fallen to probation officers-at least in the federal system-see Note, The Presentence Report: An Empirical Study of its Use in the Federal Criminal Process, 58 GEO. L.J. 451, 454-55 (1970) [hereinafter cited as "Note, Presentence Report"]; Fennell \& Hall, Due Process at Sentencing: An Empirical and Legal Analysis of the Disclosure of Presentence Reports in Federal Courts, 93 Harv. L. Rev. 1615, 1623 (1980).

76. "[B]ecause an overwhelming majority of defendants plead guilty and therefore forego trial, the report often substitutes for the trial itself as a mechanism through which facts are found in a criminal case." Fennell \& Hall, supra note 75, at 1627 (footnote omitted). See also Note, Procedural Due Process at Judicial Sentencing For Felony, 81 HARv. L. REv. 821, 836-37 (1968).

77. See N.Y. Crim. Proc. LaW \$390.20(1) (McKinney 1983) (after felony conviction, "the court must order a pre-sentence investigation of the defendant and it may not pronounce sentence until it has received a written report of such investigation").

78. See VA. CODE \& 19.2-299 (1983) (court "shall" order report "on the motion of the defendant"). 
covery, the laws as written do not necessarily dictate the practices that are followed. For instance, one of the Guggenheim judges reported that in his jurisdiction, PSI's were usually prepared for cases that were tried, but were often dispensed with in cases that pled out. ${ }^{80}$ The statute that provides for PSI's in his state does not make this distinction (if it did, you might expect it to command just the opposite of the practice), and, indeed, seems not even to admit of the possibility of waiver at. all. ${ }^{81}$ Thus local practice can undo even legislative provision for a PSI.

The literature has shown that those PSI's that are prepared often omit information, ${ }^{82}$ contain erroneous information, ${ }^{83}$ or are slanted because of

79. Georgia does not have a presentence report. Jackson v. State, $248 \mathrm{Ga} .480,484,284$ S.E.2d 267, 270-71 (1981). The closest it has is a "probation report," id., 284 S.E.2d at 270-71; see GA. CODE ANN. § 42-8-34(b) (1985) (formerly § 27-2709(b)), which is designed solely to determine whether an offender is suitable for probation, and "cannot be used in fixing the length of a sentence," McDuffie v. Jones, 248 Ga. 544, 549, 283 S.E.2d 601, 606 (1981) (emphasis in original). It is prepared at the discretion of the sentencing judge. Jackson, $248 \mathrm{Ga}$ at 484,284 S.E.2d at 271 .

80. While he was still on the bench, former Judge Rudolph F. Pierce from Massachusetts reported to the Guggenheim Project:

We have not had a tradition in our court of presentence reports, which I think is unfortunate. . . . In our court now, I use a presentence report in every case that's tried. I do not use presentence reports in every case that's pled. If the lawyers agree on the numbers and the numbers seem reasonable to me, I just don't get involved in a presentence report. If the lawyers are disagreeing on the numbers but they're fairly close (and I don't see any problems with those numbers), I don't get involved in a presentence report on a plea. If there is a wide divergence of numbers and I don't know what seems appropriate, I'll order a presentence report on a plea. But I don't as a matter of rule in every plea order a presentence report.

Remarks to Guggenheim Project, in New Haven (Dec. 15, 1984).

81. See MASs. R. CRIM. P. 28(d) (no mention of any distinction between guilty pleas or trials for preparation of PSI). Rule 28 appears to speak in mandatory terms: "The probation officer shall inquire . . ." id. at (d)(1) (emphasis added); "The report of the presentence investigation shall contain any prior criminal . . . record of the defendant . . ." id. at (d)(2) (emphasis added); "[T]he report shall include such other available information as may be helpful to the court ...," id. (emphasis added). However, because there is no explicit provision which requires these reports to be in writing, Massachusetts judges apparently let oral presentations or case intake information suffice. See Standards of Judicial Practice: Sentencing and Other Dispositions, Admin. Reg. No. 3-84 (Sept. 1984) (Admin. Off. of Dist. Ct.), reprinted in 43C MASs. Gen. LAws ANN. (West Supp. 1986) (annotation to Rule 28).

82. A 1979 study of New Haven PSI's showed that "certain items of information were frequently missing from the PSI's, even when [probation] officers were instructed to include them or [were] made aware of their importance." J. England, Presentation and Use of Presentence Information in New Haven 91 (Jun. 1, 1979) (unpublished manuscript available at Yale Law Library). For instance, about offender employment the study found:

36 per cent of the time it was impossible to tell how the defendant was employed at the time of the offense, or even whether s/he was employed at all; if the defendant were not shown to be unemployed, it was impossible to tell how long $s /$ he may have been employed when the offense was committed over 60 per cent of the time; alternatively, length of time unemployed at the time of the offense was not shown in 25 of the 35 cases where the defendant was shown to have been other than unemployed, or about 71 per cent of the time. It was more often possible to determine a defendant's employment status at disposition, but only because a large number of defendants were unemployed as a result of pre-trial detention or a loss of job after arrest. Even then, it was not reported in 40 per cent of the cases (or about 56 per cent of the cases with defendants shown to be other than unemployed) how long the defendant had been unemployed.

Id. at 46-47 (footnotes omitted). See also id. at app. C.

83. See Fennell \& Hall, supra note 75, at 1628-30; Note, A Proposal to Ensure Accuracy in 
the bias of the probation officer. ${ }^{84}$ The reasons for this are straightforward enough. Because of limited resources and worries about intruding on the privacy of those who will eventually be found innocent, ${ }^{85}$ the probation officer generally does not begin the investigation until after guilt has been established, which is weeks, months, or years after the offense has taken place. ${ }^{86}$ Evidence is now stale. Witnesses may no longer be available. And if there are disputes over the details of the offense, they will get harder to resolve as the crime fades further into history.

Moreover, the professional ethic of a probation officer is that he is not supposed merely to report the facts, but also to interpret them. ${ }^{87}$ In an office which "combines the role of therapist with that of peace officer," it is easy to see how the facts might take on a pro-state slant, a phenomenon which has been reported often. ${ }^{89}$

Presentence Investigation Reports 91 YALE L.J. 1225, 1226 (1982) [hereinafter cited as Accuragy Proposal]; Project, Parole Release Decisionmaking and the Senteneing Process, 84 YALE L.J. 810, 878 \& n.333 (1975). For specific examples of errors in descriptions of offenses, see, e.g., D. NewMan, Conviction: THE DETERMination OF GUILT OR INNOCENCE WITHOUT TRIAL 223 (1966) ("knife" that PSI reported offender had carried during commission of crime turned out to be pocketknife offender always carried which was folded and in pocket at time of offense); Portman, The Defense Lawyer's New Role in the Sentencing Process, FED. Probation, March 1970, at 3, 6 (PSI omitted provocation that immediately preceded assault); Lehrich, The Use and Disclosure of Presentence Reports in the United States, 47 F.R.D. 225, 242-44 (1969) (listing several examples of erroneous information in PSI's).

84. See P. Keve, The Probation Officer Investigates 45-46 (1960) (examples of probation officer bias); Fennell \& Hall, supra note 75, at $1667 \mathrm{n} .214$ (reports of lapses in probation officer neutrality); Justice Jeffrey M. Atlas, Remarks to Guggenheim Sentencing Project, in New Haven (Oct. 12, 1984) ("[I]n our county . . . the probation officers have a bias when they start. So you're looking for the bias and then you've got to try to offset it.") (tape recording on file with Guggenheim Project).

85. See Note, Presentence Report, supra note 75, at 465-69 (discussing disadvantages of beginning presentence investigation before determination of guilt).

86. H. Aabainsky, Probation \& Parole: Theory \& Practice 71 (2d ed. 1982) (PSI "usually made after the conviction of a defendant"). In general, a rule of investigations "that is self-evident and universally recognized and yet which is too often neglected is to make the investigation just as quickly after the fact has occurred as possible ...." Hornaday, Some Suggestions on the Investigation of Facts, 15 IND. L.J. 498, 499 (1940) (author former FBI agent).

87. A. Smith \& L. Berlin, Introduction to Probation \& Parole 35 (1976) ("A compilation of facts and descriptions of behavior is meaningless without analysis and interpretation in the light of psychiatric, psychological and sociological concepts."); P. KEvE, supra note 84, at 67 ("the probation officer is looking at that offense not for its own sake but as one facet of his client's personality, one symptom of his inner maladjustment").

88. A. SMITH \& L. BERLIN, supra note 87 , at 93 . The roots of the probation officer as peace officer reach back to 1878 , when the very first paid probation officer in the United States was directed by the supervisor of police. R. Henningsen, Probation and Parole 14 (1981).

89. As observed about New Haven PSI's: "It is an unavoidable observation that the evaluative sections of the PSI's frequently appear for all the world as if they had been lifted from a prosecuting attorney's sentencing argument." J. England, supra note 82, at 91. A federal Assistant Chief of Probation wrote in the 1960's: "Here are some examples of bias I have found in reports: 'He is a cheap, crooked swindler.' 'Never have I dealt with such a liar." "Evjen, Some Guidelines in Preparing Presentence Reports, 37 F.R.D. 177, 179 (1964) (paper delivered at Institutes on Sentencing, U.S. Judicial Conference). See also Fennell \& Hall, supra note 75, at 1667 n.214; Justice Jeffrey M. Atlas, Remarks to Guggenheim Sentencing Project, in New Haven (Oct. 12, 1984) (discussing probation officer "antagonism" toward some defendants) (tape on file with Guggenheim Project). 
Even when the probation officer himself has no such bias, the pressure of caseload, ever-present in the criminal justice system, may impose a slant on the PSI. Because of overwork, ${ }^{90}$ the probation officer may rely excessively on the prosecutor's files for information, files filled with facts which, though collected by an adversarial party, have never been tested through adversarial means. ${ }^{91}$ Similar information from the defense counsel may not be forthcoming, either because of caseload, custom, or a lack of diligence. ${ }^{82}$

Recognizing the problem of inaccuracies and misrepresentations in PSI's, a number of jurisdictions have enacted provisions designed to correct their errors. ${ }^{93}$ These reforms have focused largely on disclosing the PSI's before sentencing so that defendants can dispute any erroneous information. Disclosure laws now range from making the PSI available to defense counsel and allowing him to cross-examine the probation officer who wrote the report, to allowing the court to withhold crucial parts of the report. ${ }^{94}$ Again, the extent to which different counsel avail themselves of these statutory protections will affect the accuracy with which the facts are developed. For instance, when the federal rules were first amended to require PSI disclosure upon an attorney's request, sizeable portions of the defense bar never bothered to exercise their new privilege. ${ }^{95}$ Similarly,

90. See J. Williams, The Law of Sentencing and Correction 15 (1974) ("Probation officers are overworked and rushed because they have to produce reports at the convenience of the court."); Taparauskas, An Argument for Confrontation at Sentencing: Bringing the Offender into the Sentencing Process, 8 CuM. L. REv. 403, 421 (1977) ("Presentence reports are produced, for the most part, by underpaid, overworked members of the probation department.")

91. Note, Procedural Due Process at Judicial Sentencing for Felony, supra note 76, at 837 (probation officers "are likely to rely uncritically on reports supplied by the prosecutor, who cannot be expected to be disinterested") (footnote omitted). See also J. Williams, supra note 90, at 15-16 (information obtained from prosecutor has "inevitable tendency to prejudice the defendant").

92. See supra note 48 for discussion of the failure of many defense attorneys to be strong advocates.

93. For the history of the law of PSI disclosure and its development in the federal courts, see Fennell \& Hall, supra note 75, at 1630-40. For discussion of the different procedures district courts may employ when facts in the PSI are disputed, see United States v. Charmer Indus., 711 F.2d 1164, 1172 (2d Cir. 1983); United States v. Stephens, 699 F.2d 534, 537-38 (11th Cir. 1983). For a critique of the correction process, see Accuracy Proposal, supra note 83.

94. In Virginia, the probation officer must present his report to the sentencer in the presence of the accused in open court, having furnished a copy of the report to defense counsel at least five days earlier. VA. CoDE $\S 19.2-299$ (1983). The defendant has a right to cross-examine the probation officer on any matter in the report, and also to present any additional relevant information. Id.

On the other hand, subject to appellate review, New York courts may withhold from disclosure "a diagnostic opinion which might seriously disrupt a program of rehabilitation, or sources of information which have been obtained on a promise of confidentiality, or any other portion [of the PSI], disclosure of which would not be in the interest of justice." N.Y. CRIM. PROC. LAw $\$ 390.50(2)$ (McKinney Supp. 1986). And although the defendant does have the right to make written submissions to the court, id. at $\S 390.40$, he has no right to cross-examine the officer who prepared the report. Indeed, the question of whether even to hold a pre-sentence conference to resolve factual issues is within the discretion of the judge. Id. at $\$ 400.10$.

95. Fennell \& Hall, supra note 75 , at $1640-43$. Fennell and Hall partly attribute this attorney inaction to judges' discouraging attitudes toward disclosure, partly to the fact that defense counsel 
although New York law requires disclosure of the PSI one day before sentencing, ${ }^{96}$ in the courtrooms of the Guggenheim judges from New York, the PSI's sometimes were not delivered to the judge until the day of the sentencing, and counsel would not pick them up-if they did so at all-until minutes before the sentencing. ${ }^{97}$

\section{b. The Sentencing Hearing}

At the sentencing hearing itself, there is wide room for procedural variation. At the most basic level, a single constitutionally required standard of proof at sentencing has never been required. ${ }^{88}$ Thus different federal district court judges may apply different standards of proof. ${ }^{99}$ Likewise, the choice of what procedures are used at the sentencing hearing itself has been left largely within the discretion of the sentencing judge. ${ }^{100}$

Judges have used this license to fashion very different sentencing procedures. For instance, in the jurisdiction of one of the Guggenheim judges, it is not customary for the prosecutor even to appear in court at the sentencing hearing. ${ }^{101}$ In another, not only was the prosecutor always present, but if doubt was cast on parts of the PSI during the course of the hearing, the judge would call in the probation officer who wrote it to quiz him

were not always notified of the right to see the PSI, and partly to the lack of an activist defense bar in certain localities. Id. See also Dickey, The Lawyer and the Accuracy of the Presentence Report, FED. Probation, June 1979, at 28, 38 (significant number of Wisconsin lawyers did not bother to read PSI).

96. N.Y. Grim. Proc. Law § 390.50(2) (McKinney Supp. 1986).

97. Field observations of Justice Harold J. Rothwax's courtroom, in New York City (Feb.-Mar. 1984); Interview with Justice Jeffrey M. Atlas, in New Haven (Mar. 28, 1986). Justice Atlas reported an astonishing lack of attention to a PSI by counsel: "I sentenced a guy in a murder case last week. The defense lawyer never bothered to read the probation report-we watched him. The D.A.'s frequently don't read them either."

98. See United States v. Fatico, 603 F.2d 1053, 1057 n.9 (2d Cir. 1979), cert. denied, 444 U.S. 1073 (1980) (declining to adopt specific standard of proof at sentencing).

99. Indeed, in United States v. Fatico, 458 F. Supp. 388, 409 (E.D.N.Y. 1978), affd, 603 F.2d 1053 (2d Cir. 1979), cert. denied, 444 U.S. 1073 (1980), Judge Weinstein suggested that the same judge might properly apply different standards of proof in different cases or for different kinds of facts.

100. See United States v. Needles, 472 F.2d 652, 658 (2d Cir. 1973) ("[T]his court has generally left the decision as to the appropriateness in any particular case of these procedures largely to the discretion of the sentencing judge."); United States v. Charmer Indus., 711 F.2d 1164, 1172 (2d Cir. 1983) (listing different allowable procedures). Cf. Williams v. New York, 337 U.S. 241, 251 (1949) ("The due process clause should not be treated as a device for freezing the evidential procedure of sentencing into the mold of trial procedure.").

101. In the Cuyahoga County Court of Common Pleas in Cleveland, Ohio, the prosecutor usually does not appear at the sentencing hearing. Judge Burt W. Griffin, Remarks to Guggenheim Sentencing Project, in New Haven (Jan. 27-28, 1984). In addition, Ohio judges are discouraged from participating in the plea negotiation or making a promise to induce a plea. Id. While the sentencing judge reads the state's version of the offense in the PSI, the prosecutor's absence at the sentencing hearing means the judge may never hear adversaries present their versions of the facts and rebut their opposition's. 
about where he got the information and would sometimes even ask to see his notes. ${ }^{102}$

A method that these two judges share, however, is close personal questioning of defendants. Both engaged in extensive colloquys with the defendants at the sentencing hearing-hashing out the offense once again, delving into every circumstance that might bear on the sentence. Another of the Guggenheim judges followed a sharply contrasting practice. He would not commit himself to a sentence before the guilty plea, but after the plea had been entered, he would usually impose a sentence that both attorneys could agree on. ${ }^{103}$ If counsel both recommended a certain sentence-or if they recommended sentences which were very close-the judge would dispense with the PSI and with any detailed inquisition of the defendant at the sentencing hearing and impose the recommended sentence. $^{104}$

The enormous flexibility in the procedures allowed at a sentencing hearing thus magnifies the temperament of the sentencing judge. And because it is part of the lore of every courtroom that some judges take more time and care in conducting factfinding than do others, ${ }^{105}$ this flexibility allows the development of varying factual descriptions for similar crimes.

\section{STRIVING FOR ACCURACY}

From the initial interviews in a case to the hearing at which the judge imposes the sentence, the criminal justice system presents occasions for misdescription of sentencing facts. In this essay, I have argued that the flexibility of procedures-both as established by rule or statute and as "amended" by local custom - allows an unwarranted degree of error. My evidence, however, has been largely anecdotal. Further work needs to be done to try to discover just how great and how regular factual errors are. If closer study confirms my hypothesis, then lawmakers will need to reform factfinding procedures if they are truly to curtail disparity.

In framing the reforms, legislatures and sentencing commissions will be forced to make unpleasant choices. Many of the procedures that can reduce factfinding errors take time and money. Lawmakers should be

102. Justice Jeffrey M. Atlas, Remarks to Guggenheim Sentencing Project, in New Haven (Oct. 12 , 1984) (tape on file with Guggenheim Project).

103. Judge Rudolph F. Pierce, Remarks to Guggenheim Sentencing Project, in New Haven (Dec. 15, 1984) (tape on file with Guggenheim Project).

104. Id. The judge reports he would go behind the numbers only if something "smelled wrong."

105. The varying care with which different judges examine the facts of a case are known even by the defendant population. A probation officer interviewed by a Guggenheim researcher told a story of a defendant who had been uncooperative with the officer in a previous case. This time the defendant was to be sentenced by Judge Frederick Weisberg (the judge being studied by the researcher), and cooperated because of the Judge's reputation for fully considering the information in the PSI. Weisberg Profile, supra note 71 , at 32 . 
guided by a simple principle: if they have chosen to make a given fact substantively relevant to a sentence, then they should ensure that the procedural machinery exists to describe that fact accurately to the sentencer. It makes little sense to engineer a substantive sentencing law refined enough to take into account detailed information unless the procedures can withstand the stress of being asked to describe those details accurately in the daily operation of the criminal justice system. Without this fit between substance and procedure, sentencing reform presents a nasty paradox: we care enough about a fact to change a sentence when we know the fact exists, but we don't care enough about the same fact to put in place procedures that tell us accurately when it exists and when it doesn't. This is a clear recipe for disparity.

In adjusting the fit, lawmakers can work both sides of the equation; they can tinker either with the substantive law or with the procedure. That is, one way of dealing with the problem is to decide how much procedure we are willing to pay for and then match the substantively relevant facts to those procedures. The other is first to decide what facts are substantively relevant, and then to pay whatever it costs to develop those facts accurately. From the point of view of disparity, either approach is acceptable.

It will take time, however, for lawmakers to close the gap between the substance and the procedure of sentencing. In the meantime, the very existence of guidelines provides various actors with tools to coax more accurate facts out of the current system.

\section{A. Better Identification of Relevant Facts}

In a way never done before, the existence of sentencing guidelines will identify for litigants the issues important to the sentence. Because prosecutors boast such high conviction rates, ${ }^{108}$ the critical question for a majority of defendants is not "guilty or not guilty?" but "how long?"107 In a nonguideline system, an attorney trying to litigate the "how-long?" question is in a quandary. He may not know what facts matter to the judge, or how the facts that do matter will affect the sentence, ${ }^{108}$ and thus does not even know exactly what facts to investigate. It is as if he were trying to

106. In New York State in 1983 , convictions accounted for $85 \%$ of all felony dispositions. N.Y. GuIDELINE REPORT, supra note 7, at 26.

107. See Kuh, Defense Counsel's Role, supra note 43, at 433 ("Recognizing that the majority of seriously charged defendants are guilty of something, and that prospective sentencing is a prime concern of theirs, their attorneys should be pointing toward the day of sentence from the first client meeting . . . ."); Lehrich, supra note 83, at 225 ("[T]he crucial determination for most criminal defendants is not that of guilt or innocence, but that of the sentence to be imposed.").

108. See supra text accompanying note $2-5$. 
prepare to try a burglary case without knowing the statutory elements of burglary.

By telling lawyers what facts will affect sentences, guideline systems can make lawyers' investigation and preparation for sentencing litigation more intelligent. It will be possible to sit down with a guideline manual and the case law on permissible and impermissible departures and write a kind of sentencing checklist, ${ }^{109}$ a litigation outline for sentencing. Focusing the lawyers' attention on the salient facts should raise the quality of sentencing litigation and bring more information to the judge.

\section{B. Generating Accuracy through Habeas Corpus}

Prisoners can exert pressure for early accuracy in the system through habeas corpus actions. Since the 1940's, defendants have enjoyed a constitutional right to be sentenced on the basis of accurate facts. ${ }^{110}$ However, offenders have gotten little mileage out of this constitutional guarantee because of two doctrines of traditional sentencing law. First, nobody defines for judges what facts are or are not relevant to a sentence. ${ }^{111}$ Second, judges are not required to state for the record which facts they are relying on or how far those facts move the sentence up or down. ${ }^{112}$ Put together, the doctrines make it difficult indeed to show that erroneous information

109. Minnesota judges and Federal Parole Hearing Examiners already use various checklists to help apply the guidelines. See MinN. Stat. AnN. ch. 244-app. (Supp. 1985) (Minnesota Sentemcing Guidelines \& Commentary) (Forms) (reproduction of "Sentencing Worksheet"); 28 C.F.R. \& 2.20 (1985) (reproduction of "Salient Factor Score" worksheet). Neither of these checklists thoroughly covers the full range of factors which the guidelines and departure policy allow the sentencer to take into account, however.

110. See Townsend v. Burke, 334 U.S. 736, 741 (1948) ("IT]his prisoner was sentenced on the basis of assumptions concerning his criminal record which were materially untrue. Such a result, whether caused by carelessness or design, is inconsistent with due process of law. . . ."). See also Roberts v. United States, 445 U.S. 552, 556 (1980) ("We have . . . sustained due process objections to sentences imposed on the basis of 'misinformation of constitutional magnitude." "); United States $v$. Tucker, 404 U.S. 443, 447-48 (1972) (affirming circuit court's remand for resentencing because original sentence was predicated on inaccurate information); United States v. Jones, 640 F.2d 284, 286 (10th Cir. 1981) ("ISupreme Court] cases recognize a due process right to be sentenced only on information which is accurate."); United States v. Tobias, 662 F.2d 381, 388 (5th Cir. 1981) ("Sentences based upon erroneous and material information or assumptions violate due process."), cert. denied, 457 U.S. 1108 (1982).

111. See Dobbert v. Strickland, 718 F.2d 1518, 1524 (11th Cir. 1983) ("Whether particular evidence . . . is mitigating depends on the evidence in the case as a whole and the views of the sentencing and reviewing judges. What one person may view as mitigating, another may not."), cert. denied, 104 S.Ct. 3591 (1984); Legislative AGenda, supra note 1, at 3 ("Sentencing judges are thus left free to formulate and apply their own personal theories of punishment.") (footnote omitted).

112. United States v. Garcia, 617 F.2d 1176, 1178 (5th Cir. 1980) (no requirement that courts announce reasons for sentences); United States v. Inmon, 594 F.2d 352, 354 (3d Cir. 1979) ("Enunciating reasons for a sentence has never been held to be a constitutional requirement."). In fact, current incentives push trial courts to omit reasons, because, once given, reasons can be considered as a basis for vacating sentences. See United States v. Vasquez, 638 F.2d 507, 534 (2d Cir. 1980) (once reasons given, basis for sentence can be scrutinized), cert. denied, 450 U.S. 970, 454 U.S. 847, and Vasquez v. United States, 454 U.S. 975 (1981). 
affected the length of a sentence. ${ }^{113}$ Yet in order to have a sentence vacated because it is predicated on erroneous information, an offender must show that the court did, in fact, rely on a specific piece of mistaken information. ${ }^{114}$

Sentencing guidelines cast new light on facts used in sentencing. By the very act of choosing a specific box in a sentencing grid, a judge is making certain implicit findings of fact. And to depart from the range in a box, a judge must explicitly state the reasons for doing so. Thus, one way or another, the guidelines bring into the open the facts that a sentencing judge is relying on, and explain exactly how those facts affect the sentence. As the problems of showing reliance and harm consequently diminish, post-conviction attacks on the accuracy of the factual predicate of sentences should develop new muscle, and prosecutors and judges will be encouraged to pay more attention to the accuracy of the facts at earlier stages of the process in order to ensure the finality of sentencing decisions.

\section{CoNCLUSION}

When the issue of factfinding came up in the New York Committee on Sentencing Guidelines, the minutes of the meeting report that Robert Morgenthau, District Attorney for Manhattan "said that the bottom line was that the system could not include a lot of fact-finding."116 But as Jerome Frank has said: "No matter . . . how excellent the 'substantive' legal rules (the R's) and the social policies they embody, specific decisions will go astray, absent competent fact-finding."116

113. "A Sphinx-like silence on the court's part precludes anyone (including the parties, the judge, and an appellate tribunal) from learning whether he acted in error." United States v. Brown, 479 F.2d 1170, 1173 (2d Cir. 1973); United States v. Green, 680 F.2d 183, 204 (D.C. Cir. 1982) (Bazelon J., dissenting) (the majority's rule "adopts a mechanistic view of sentencing that challenges the defendant to find that one special fact that would push a lever marked 'leniency' in the sentencing judge's mind"), cert. denied, 459 U.S. 1210 (1983).

114. United States ex rel. Welch v. Lane, 738 F.2d 863, 865 (7th Cir. 1984) (defendant must show that "sentencing court relied on the misinformation in passing sentence"); United States v. Cimino, 659 F.2d 535, 537 (5th Cir. 1981) ("To prevail on a claim that a sentence was based on materially inaccurate information, an appellant must demonstrate that a court relied on that information.") (emphasis in original) (footnote omitted). But see United States v. Baylin, 696 F.2d 1030, 1042 (3d Cir. 1982) (remanding for resentencing because unreliable information may have added to sentence).

115. Minutes of the Meeting of New York State Committee on Sentencing Guidelines 3 (Apr. 27, 1984).

116. In re Fried, 161 F.2d 453, 464 (2d Cir.), cert. granted, United States v. Fried, 331 U.S. 804 , cert. dismissed, 332 U.S. 807, cert. denied, 331 U.S. 858 (1947). 